\title{
KELAYAKAN CD INTERAKTIF PADA SUBMATERI ORGAN TUMBUHAN DI KELAS XI SMA
}

\author{
Rati Utami ${ }^{1}$, Entin Daningsih ${ }^{2}$, Reni Marlina ${ }^{3}$ \\ ${ }^{1,2,3}$ Program Studi Pendidikan Biologi, FKIP Universitas Tanjungpura \\ Jalan Prof. Dr. H. Hadari Nawawi Pontianak 78124 \\ e-mail: ratih0428@gmail.com
}

\begin{abstract}
Abstrak
Penelitian bertujuan untuk menguji kelayakan $\mathrm{CD}$ interaktif sebagai media pembelajaran pada submateri organ tumbuhan di kelas XI. Penelitian menggunakan metode deskriptif. Pembuatan CD interaktif dilakukan dengan memasukkan media teks, gambar, audio, animasi, dan video menggunakan aplikasi Adobe Flash Professional CC 2015. Validasi media dilakukan oleh enam orang validator yang terdiri dari tiga ahli materi dan tiga ahli media. Ahli materi terdiri dari satu orang dosen Pendidikan Biologi dan dua orang guru Biologi yang menggunakan KTSP. Ahli media terdiri dari dua orang dosen ahli media dan guru Teknologi Informasi dan Komunikasi. Validasi CD interaktif oleh ahli materi diperoleh $\mathrm{RTV}_{\mathrm{tk}}$ sebesar 3,63, sedangkan validasi oleh ahli media diperoleh $\mathrm{RTV}_{\mathrm{tk}}$ 3,72 . Hasil validasi menyatakan bahwa media $C D$ interaktif layak digunakan dalam proses pembelajaran pada organ tumbuhan.
\end{abstract}

Kata Kunci: kelayakan, CD interaktif organ tumbuhan, validasi.

\begin{abstract}
This study aimed to examine the feasibility of an interactive $C D$ as a learning medium on sub-materials plant organs in grade XI. This research used descriptive method. Making interactive CD was done by inserting text, image, audio, animation and video media using Adobe Flash Professional CC 2015 applications. Media validation was carry out by six validators consisted of three material experts and three media experts. The material expert consisted of one lecturer of biology education and two biology teachers used KTSP curriculum. Media experts consisted of two lecturers and teacher of Information and Communication Technology. Interactive CD validation by expert material obtained RTVtk of 3.63, while validation by media expert obtained RTVtk 3.72. The validation results showed that interactive CD media was suitable for using in the learning process in the plant organs.
\end{abstract}

Keywords: feasibility, plant organ interactive $C D$, validation.

\section{PENDAHULUAN}

Media adalah alat atau sarana yang dapat membantu proses belajar mengajar dan berfungsi untuk memperjelas atau memperkuat makna pesan yang disampaikan, sehingga dapat mencapai tujuan pembelajaran dengan lebih baik. Berbagai macam tipe media yang digunakan dalam pembelajaran yaitu media berbasis cetakan, media berbasis visual, audiovisual, dan komputer. 
Sadiman (2010) mengatakan bahwa media hendaknya dapat dimanipulasi, dapat dilihat, didengar, dan dibaca. Salah satu contoh media yang dapat dimanipulasi, dilihat, didengar, dan dibaca yaitu media berbasis komputer. Komputer termasuk media multifungsi yang mampu menampilkan gambar dan teks, baik berupa gambar diam atau gambar yang dapat bergerak dan bersuara (audio). Kombinasi antara gambar, teks, dan audio disebut dengan multimedia. Menurut Darmawan (2014), multimedia merupakan alat yang dapat menciptakan presentasi yang dinamis dan interaktif yang mengkombinasikan teks, grafis, animasi, audio, dan video. Interaktif berarti terdapat hubungan timbal balik antara media dan pengguna media (user).

Teknologi komputer menjadi salah satu solusi dalam penyediaan multimedia untuk mendukung pembelajaran yang lebih optimal. Hal tersebut dibuktikan dari hasil penelitian Krisnawati (2014) yang menunjukkan bahwa produk multimedia pembelajaran biologi yang dikembangkan efektif untuk pembelajaran dan dapat meningkatkan hasil belajar siswa SMA.

Salah satu pemanfaatan komputer dalam mendesain multimedia pembelajaran yang interaktif dan berbasis teknologi informasi adalah media Compact Disk (CD) interaktif. Nurmuji (2015) mengatakan bahwa media CD interaktif merupakan teknologi yang mengoptimalkan peran komputer sebagai media yang menampilkan teks, suara, video, dan animasi dalam sebuah tampilan yang terintegrasi dan interaktif sehingga dapat meningkatkan motivasi belajar siswa.

Kombinasi banyak media ke dalam karya tunggal menjadikan CD termasuk dalam multimedia interaktif. $\mathrm{CD}$ interaktif dapat digunakan dalam pembelajaran serta dapat membantu siswa belajar secara mandiri karena siswa dapat berinteraksi langsung dengan komputer yang telah diprogram. Dengan demikian CD interaktif dapat mendorong keaktifan siswa dalam mengikuti proses pembelajaran. Hal tersebut dibuktikan oleh hasil penelitian Ambarwati (2014) yang menunujukkan bahwa penerapan CD interaktif IPA terpadu berbasis science edutainment dapat meningkatkan hasil belajar dan keaktifan siswa pada tiap pertemuan. 
Biologi adalah ilmu yang membahas tentang makhluk hidup dari unit struktural yang terkecil hingga yang paling kompleks. Oleh karenanya, banyak pembelajaran biologi bersifat abstrak (absurd), salah satunya adalah submateri organ tumbuhan. Berdasarkan silabus KTSP kelas XI SMA pada kompetensi dasar 2.1 organ tumbuhan termasuk kedalam materi pokok Struktur dan Fungsi Jaringan pada Tumbuhan. Pada umumnya morfologi tumbuhan bagian luar dapat dilihat secara langsung tanpa harus menggunakan mikroskop. Namun, ada beberapa bagian dari tumbuhan yang tidak dapat dilihat dengan mata secara langsung seperti struktur jaringan dan selnya. Apabila dalam proses pembelajaran dilakukan praktikum, maka memerlukan persiapan dan perencanaan yang matang dan fasilitas peralatan laboratorium yang lengkap.

Berdasarkan hasil wawancara dengan guru bidang studi Biologi di SMA 1 Ambawang kelas XI, pembelajaran submateri organ tumbuhan tergolong mudah. Metode pembelajaran yang digunakan adalah ceramah dan diskusi kelompok. Alternatif media yang digunakan dalam menyampaikan submateri organ tumbuhan adalah Charta. Media charta memiliki kelebihan yaitu bentuknya sederhana dan biaya pembuatannya relatif murah. Namun, charta hanya berisi informasi visual yang singkat. Oleh karenanya, tujuan pemilihan media CD interaktif adalah sebagai alternatif media selain charta yang berbasis teknologi informasi dan komunikasi yang dapat mendukung proses pembelajaran berjalan lancar dan mendorong aktivitas belajar siswa.

Kelebihan CD sebagai multimedia interaktif dibandingkan media lainnya menurut Munir (2013) adalah mampu menggabungkan antara teks, gambar, audio, musik, animasi, gambar, dan video dalam satu kesatuan yang saling mendukung guna tercapainya tujuan pembelajaran, sistem pembelajaran lebih inovatif dan interaktif, melatih peserta didik lebih mandiri dalam mendapatkan ilmu pengetahuan, menambah motivasi peserta didik selama proses pembelajaran hingga didapatkan tujuan pemebelajaran yang diinginkan, mampu memvisualisasikan materi yang selama ini sulit untuk diterangkan hanya sekedar dengan penjelasan atau alat peraga yang konvensional. 
Secara umum, media CD interaktif yang dibuat berisi konsep-konsep materi organ tumbuhan mencakup fungsi dan struktur jaringan organ akar, batang, daun, dan bunga dan sedikit informasi tambahan tentang stomata. Sehingga, tujuan dari dari penelitian adalah untuk mengetahui kelayakan media $C D$ interaktif organ tumbuhan kelas XI SMA.

\section{METODE}

Bentuk penelitian adalah penelitian deskriptif. Pemilihan sekolah mitra berdasarkan beberapa aspek, yaitu: kurikulum yang digunakan KTSP, adanya sarana dan prasarana laboratori um komputer dan LCD proyektor, adanya program IPA, dan akreditasi sekolah minimal B. Alat yang digunakan dalam penelitian adalah laptop, CD blank, dan software. Bahan yang digunakan adalah data dari hasil analisis ukuran dan tipe stomata tumbuhan, gambar/foto, video, animasi, audio, dan teks rangkuman submateri organ tumbuhan kelas XI.

Langkah-langkah dalam penyusunan CD interaktif organ tumbuhan yaitu melakukan analisis kurikulum, menentukan SK, KD, indikator, dan tujuan pembelajaran yang dijadikan bahan untuk pembuatan media. Dalam penelitian yang dilakukan menggunakan KTSP. Kemudian memilih software, jenis software yang digunakan adalah software Adode Professional CC 2015. Kemudian merancang desain CD interaktif organ tumbuhan seperti desain tampilan, teks, gambar, video, animasi, dan audio. Selanjutnya mengumpulkan media berupa hasil penelitian, gambar/foto, animasi, video, dan audio dari berbagai sumber seperti internet dan buku ajar. Setelah bahan-bahan yang diperlukan seperti materi/konsep sudah selesai dirangkum maka pengerjaan CD interaktif organ tumbuhan dimulai. Setelah pembuatan media selesai, dilakukan validasi atau dinilai oleh validator.

Pada penelitian yang dilkukan, evaluasi media dilakukan dengan uji validitas. Uji validasi terbagi menjadi 2 tahapan, yaitu pengujian validitas instrumen dan pengujian validitas CD interaktif organ tumbuhan. Uji validitas instrumen pada penelitian dilakukan dengan tujuan untuk mengukur kelayakan lembar validasi yang akan digunakan untuk memvalidasi media pembelajaran, 
supaya instrumen yang digunakan layak untuk menguji media pembelajaran. Para ahli akan memberi keputusan: instrumen dapat digunakan tanpa perbaikan (LD), ada perbaikan (LDP), dan mungkin dirombak total (TLD).

Pada evaluasi media dilakukan dengan uji validitas menggunakan instrumen yang telah divalidasi kelayakannya. Validasi media CD interaktif dilakukan 3 orang ahli materi dan 3 orang ahli media. Ahli materi terdiri atas 1 orang dosen Pendidikan Biologi FKIP Untan dan 2 orang guru Biologi SMA yang mengajarkan submateri organ tumbuhan kelas XI yang berasal dari SMA Santun Untan Pontianak dan SMA Swasta Islam Bawari Pontianak. Ahli media terdiri atas dosen Prodi Sistem Komputer dari kampus MIPA Untan, dosen Universitas Muhammadiyah Pontianak, dan guru TIK dari SMAN 1 Sungai Ambawang. Pemilihan sekolah mitra menggunakan teknik purposive sampling.

Kriteria validasi pada penelitian untuk ahli materi meliputi aspek format, isi, dan bahasa. Sedangkan untuk ahli media meliputi aspek komunikasi visual dan audio, desain pembelajaran, dan rekayasa perangkat lunak. Langkah-langkah dalam menganalisis data, yaitu memasukkan data ke dalam tabel, mencari ratarata per kriteria, mencari rata-rata tiap aspek, mencari rata-rata total validitas ketiga aspek, kemudian menentukan kategori kevalidan dengan mencocokan ratarata total dengan kriteria kevalidan, yaitu: $3 \leq \mathrm{RTV} \leq 4$ valid (layak), $2 \leq \mathrm{RTV}<3$ kurang valid, dan $1 \leq \mathrm{RTV}<2$ tidak valid.

\section{HASIL DAN PEMBAHASAN}

Hasil dari penelitian diimplementasikan menjadi sebuah media pembelajaran pada materi organ tumbuhan kelas XI SMA. Berikut merupakan tampilan media CD interaktif pada sub materi organ tumbuhan kelas XI SMA (Gambar 1). 

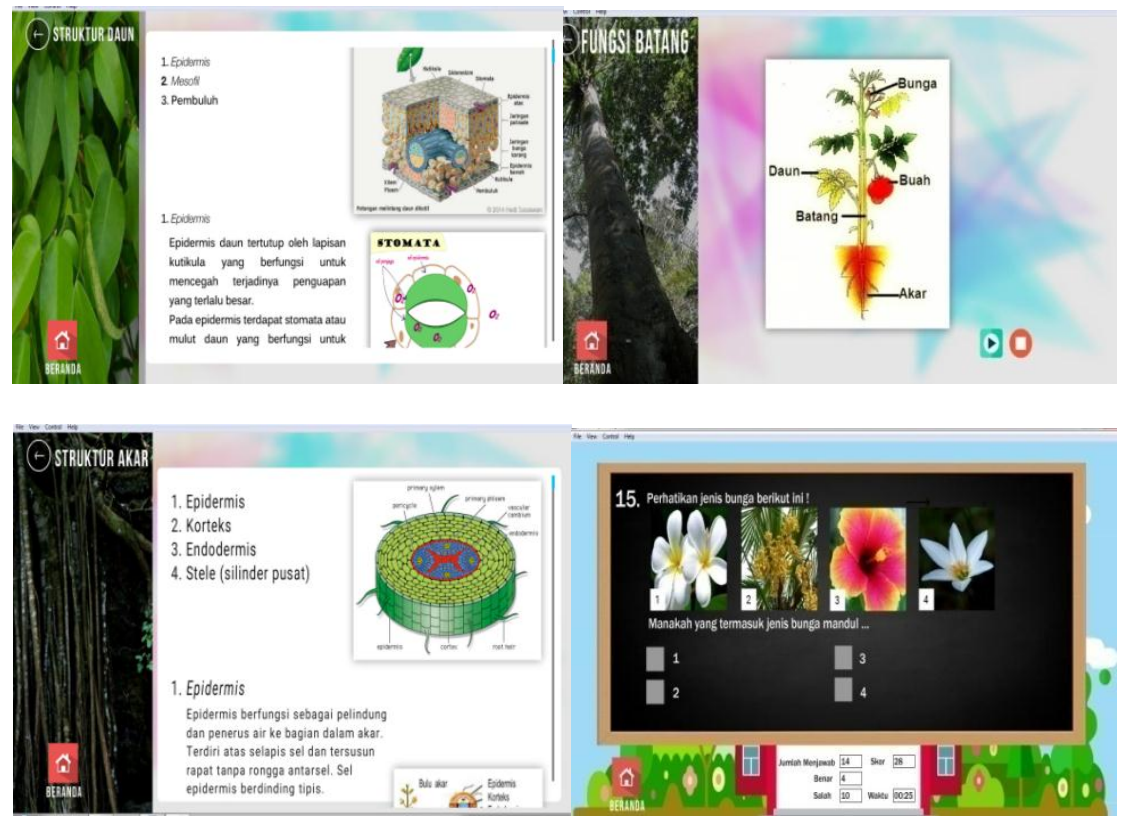

Gambar 1 Tampilan CD Interaktif yang Memuat Sub Materi Organ Tumbuhan

Kelayakan media CD interaktif ditinjau dari kelayakan materi dan kelayakan media. Berikut merupakan data hasil analisis validasi media CD interaktif (Tabel 1).

Tabel 1 Data Hasil Analisis Media CD Interaktif Organ Tumbuhan yang Dilakukan oleh Ahli Materi

\begin{tabular}{|c|c|c|c|c|c|c|}
\hline \multirow{2}{*}{ Aspek } & \multirow{2}{*}{ Kriteria } & \multicolumn{3}{|c|}{ Validator } & \multirow{2}{*}{$\mathbf{K i}$} & \multirow{2}{*}{$\mathbf{A} \mathbf{i}$} \\
\hline & & 1 & 2 & 3 & & \\
\hline \multirow[t]{5}{*}{ Format } & $\begin{array}{l}\text { 1. Petunjuk pengerjaan soal mudah } \\
\text { dipahami }\end{array}$ & 4 & 4 & 4 & 4 & \multirow[t]{5}{*}{3,73} \\
\hline & $\begin{array}{l}\text { 2. Keserasian warna tulisan pada media } \\
\text { pembelajaran }\end{array}$ & 3 & 4 & 4 & 3,67 & \\
\hline & $\begin{array}{l}\text { 3. Kesesuaian tampilan gambar dan } \\
\text { tulisan pada soal evaluasi }\end{array}$ & 4 & 3 & 4 & 3,67 & \\
\hline & $\begin{array}{l}\text { 4. Menggabungkan unsur audio dan } \\
\text { visual atau dapat memberikan } \\
\text { informasi berupa teks, audio, gambar, } \\
\text { video, dan animasi yang mendukung } \\
\text { materi organ tumbuhan kelas XI }\end{array}$ & 3 & 4 & 4 & 3,67 & \\
\hline & $\begin{array}{l}\text { 5. Animasi, gambar dan video } \\
\text { memperkuat materi yang disajikan }\end{array}$ & 3 & 4 & 4 & 3,67 & \\
\hline \multirow[t]{2}{*}{ Isi } & $\begin{array}{l}\text { 6. Materi yang terdapat pada CD sesuai } \\
\text { dengan silabus, kompetensi dasar dan } \\
\text { tujuan pembelajaran }\end{array}$ & 3 & 4 & 4 & 3,67 & \multirow[t]{2}{*}{3,5} \\
\hline & 7. Keringkasan materi & 3 & 4 & 4 & 3,67 & \\
\hline
\end{tabular}




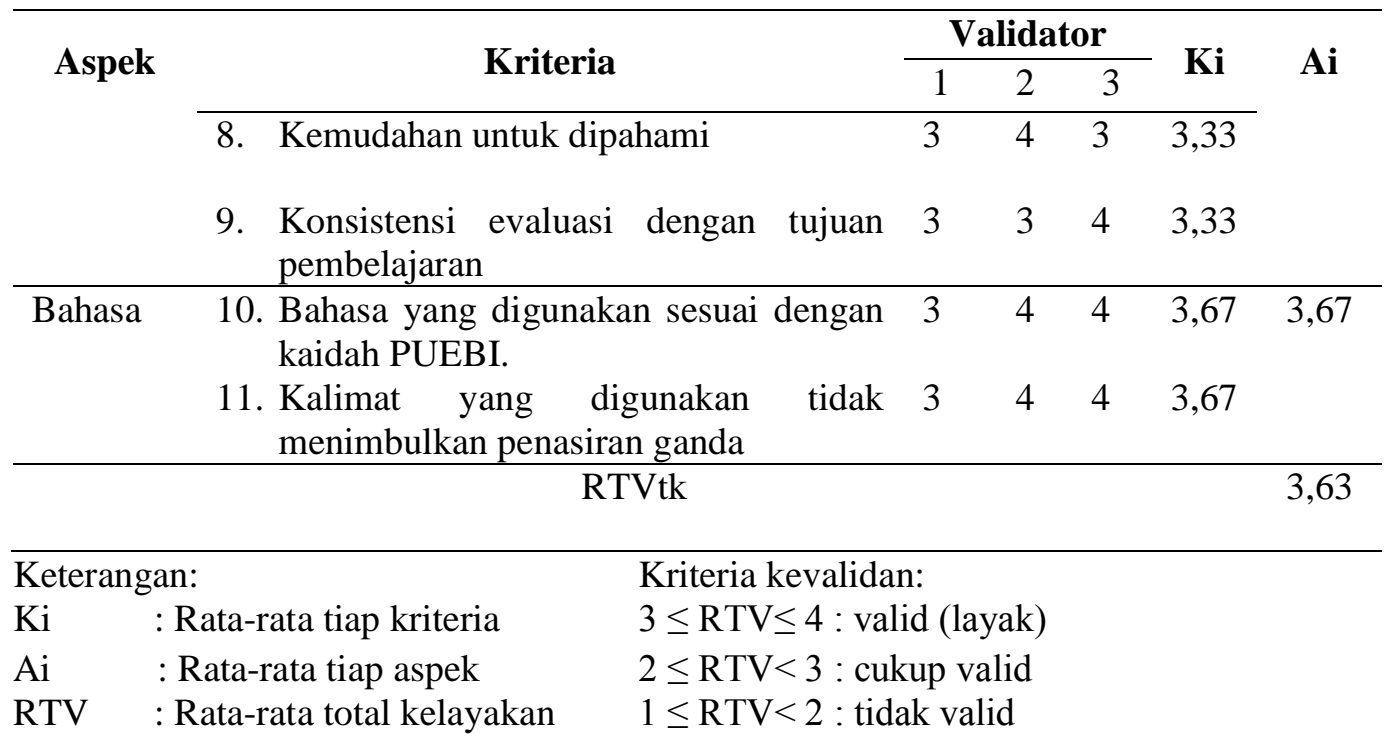

Seluruh aspek yang dinilai mendapatkan rata-rata validitas $3 \leq 3,63 \leq 4$. Hal tersebut berarti media dinyatakan valid (layak). Aspek format diketahui petunjuk pengerjaan soal mudah dipahami, jelas, dan memiliki umpan balik terhadap hasil evaluasi. Menurut Arkun dan Akkoyunia (2008) multimedia interaktif sebaiknya mengijinkan para siswa untuk membuat implementasi dan menerima umpan balik. Kemudian keserasian warna tulisan pada media pembelajaran. Warna tulisan dan latar belakang pada media kontras, jelas, dan menarik.

Menurut Amalia (2013), penggunaan warna dalam sebuah desain grafis mempunyai beberapa fungsi, yaitu untuk menarik perhatian, menghasilkan efek psikologis, mengembangkan asosiasi, membangun retensi, dan menciptakan suasana yang menyenangkan. Kemudian tampilan gambar, tulisan, dan warna gambar misalnya pada gambar struktur anatomi daun. Tulisan keterangannya jelas, dapat dilihat dari jarak $60 \mathrm{~cm}$, dan warna gambar tersebut menarik. Diartono (2008) mengungkapkan bahwa warna dapat memberikan dampak menyejukkan atau menyilaukan mata, warna dapat menarik perhatian pemakai untuk terus menggunakan aplikasi, warna dapat menambah ketegasan informasi yang diberikan, serta menarik perhatian.

Media juga menggabungkan unsur audio dan visual atau memberikan informasi berupa teks, audio, gambar, video, dan animasi yang mendukung materi 
organ tumbuhan kelas XI. Menurut Ramendra dan Ratminingsih (2007), media audio visual dapat membuat pembelajaran lebih produktif, lebih menarik, dapat meningkatkan motivasi siswa, dapat mempercepat pemahaman siswa terhadap pembelajaran, membuat guru lebih efisien memanfaatkan waktu mengajar, dan mampu membuat proses belajar lebih efektif. Selanjutnya animasi, gambar, dan video pada media memperkuat materi yang disajikan. Animasi dan video pada media dianggap menarik dan tidak mengganggu konsentrasi. Animasi dan video juga mendukung materi yang disampaikan.

Terdapat beberapa komentar dari validator pertama terhadap aspek format kriteria mengenai warna latar belakang kurang bervariasi. Hal tersebut juga disadari oleh peneliti bahwa adanya kekurangan pada media khususnya warna latar belakang. Kemudian komentar kedua datang dari validator kedua terhadap aspek format kriteria mengenai ukuran gambar yang kurang diperbesar. Nilai ratarata yang paling rendah yaitu aspek isi pada kriteria kemudahan untuk dipahami dan konsistensi evaluasi dengan tujuan pembelajaran. Hal tersebut karena ada beberapa kesulitan pada materi khususnya mengingat nama latin tumbuhan dan pada soal evaluasi dan tujuan pembelajaran kurang konsisten.

Hasil validasi media yang dilakukan oleh ahli materi mencapai skor ratarata validator adalah 3,63 sehingga media dianggap layak (valid) untuk digunakan. Berikut merupakan data hasil analisis validasi media CD interaktif (Tabel 2).

Tabel 2 Data Analisis Validasi Media CD Interaktif Organ Tumbuhan yang Dilakukan oleh Ahli Media

\begin{tabular}{|c|c|c|c|c|c|c|}
\hline \multirow{2}{*}{ Aspek } & \multirow{2}{*}{ Kriteria } & \multicolumn{3}{|c|}{ Validator } & \multirow{2}{*}{$\mathbf{K i}$} & \multirow{2}{*}{$\mathbf{A i}$} \\
\hline & & 1 & 2 & 3 & & \\
\hline \multirow{8}{*}{$\begin{array}{l}\text { Komunikasi } \\
\text { Visual dan Audio }\end{array}$} & 1. Ukuran huruf yang digunakan & 4 & 4 & 4 & 4 & 3,76 \\
\hline & dapat dibaca dengan jelas & & & & & \\
\hline & $\begin{array}{l}\text { 2. Ikon navigasi mampu } \\
\text { mengakomodasi respon } \\
\text { pengguna }\end{array}$ & 4 & 4 & 4 & 4 & \\
\hline & 3. Desain tata ruang (Layout) & 4 & 4 & 4 & 4 & \\
\hline & 4. Audio & 3 & 3 & 4 & 3,33 & \\
\hline & 5. Animasi & 4 & 3 & 4 & 3,67 & \\
\hline & 6. Video & 3 & 4 & 4 & 3,67 & \\
\hline & 7. Gambar & 4 & 3 & 4 & 3,67 & \\
\hline
\end{tabular}




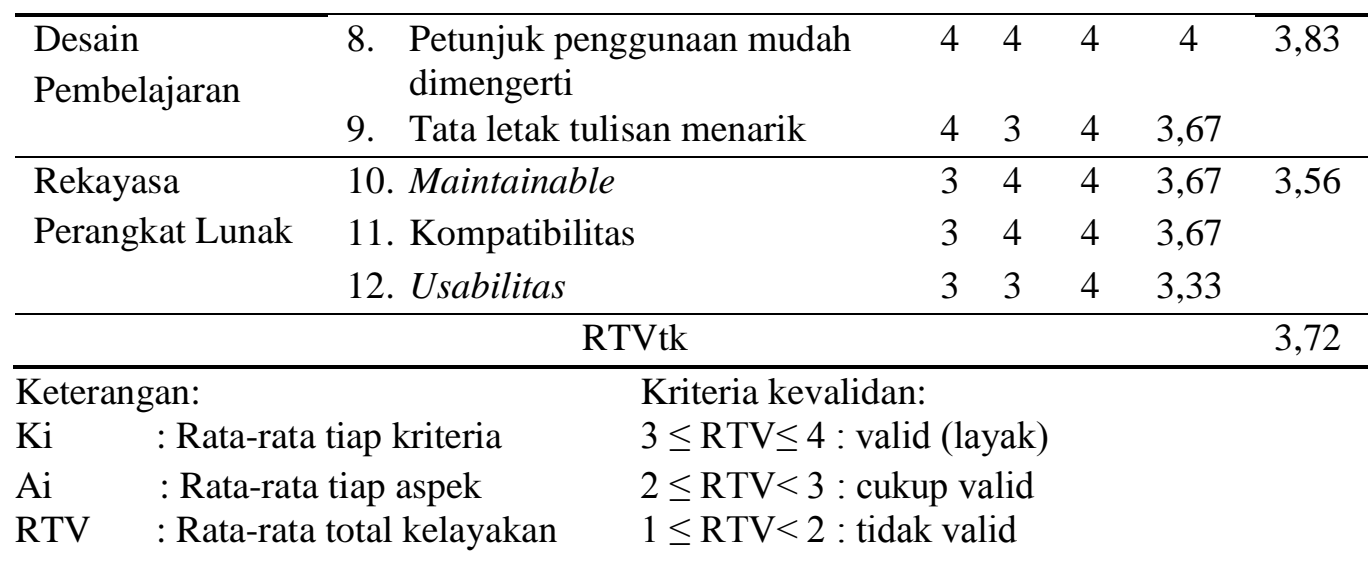

Hasil penilaian dari tiga validator pada CD interaktif didapat skor rata-rata total validitas 3.72 (Tabel 2). Sehingga nilai rata-rata total validitas $3 \leq 3,72 \leq 4$. Hal tersebut berarti media dinyatakan valid (layak). Pada aspek komunikasi visual dan audio kriteria bentuk layout sederhana, teratur, dan latar belakang kontras dengan tulisan, ikon navigasi dapat mengontrol satu frame ke frame selanjutnya, mampu mengakomodasi respons pengguna dan terstruktur, ukuran huruf konsisten, dapat dilihat dari jarak 50-60 cm, dan mudah dibaca.

Pada kriteria audio, suara yang dihasilkan jelas namun kurang jernih. Hal tersebut karena keterbatasan alat dalam proses perekaman. Salah satunya pada audio narasi fungsi akar dan batang pada CD interaktif. Menurut Yuli (2011), media audio dapat meningkatkan keterampilan berkomunikasi siswa. Selanjutnya animasi, menurut validator animasi mendukung materi yang disampaikan, memperjelas teori, dan tidak mengganggu konsentrasi, seperti animasi stomata dan proses fotosintesis yang terdapat pada materi daun. Putra (2013) mengatakan bahwa, pembelajaran sejarah dengan menggunakan media pembelajaran melalui pemanfaatan multimedia animasi interaktif dapat meningkatkan minat siswa terhadap mata pelajaran sejarah, sehingga diharapkan dapat meningkatkan prestasi belajar siswa.

Selain animasi, video juga mendapat kesan yang positif karena dalam video akar, batang, daun, dan bunga berisi informasi yang mendukung materi yang disampaikan, menarik, dan durasi video tidak melebihi 6 menit. Maya (2013) membuktikan bahwa penggunaan pembelajaran video lebih efektif dalam meningkatkan kompetensi dan pengetahuan mahasiswa. 
Adapun gambar yang terdapat dalam media mendukung teori yang disampaikan, keterangan pada gambar jelas, dan dapat dilihat dari jarak 50 - 60 $\mathrm{cm}$. Gambar yang ditampilkan merupakan gambar struktur anatomi organ akar, batang, daun, bunga, dan foto preparat stomata yang telah diamati. Hal tersebut diharapkan dapat mengurangi kebosanan dan menambah ketertarikan siswa pada materi yang disampaikan. Menurut Wardani (2013), gambar sangat baik digunakan dan diterapkan dalam proses belajar mengajar sebagai media pembelajaran karena media gambar ini cenderung sangat menarik hati siswa sehingga akan muncul motivasi untuk lebih mengetahui tentang gambar yang dijelaskan dan guru dapat menyampaikan materi dengan optimal melalui media gambar tersebut.

Rata-rata kriteria yang paling rendah yaitu aspek komunikasi visual dan audio, hal tersebut karena keterbatasan alat pada saat perekaman dan aspek rekayasa perangkat lunak pada kriteria usabillitas (kemudahan dalam penggunaan). Hal tersebut karena salah satu kekurangan media CD adalah hanya dapat digunakan pada komputer yang memiliki $C D$ room.

Penggunaan CD interaktif dapat juga diterapkan dalam pembelajaran yang menggunakan Kurikulum 2013. Walaupun CD interakif diinisiasi dengan KTSP, tetapi pada materi pokok Struktur dan Fungsi Jaringan pada tumbuhan yang terdapat pada silabus KTSP sama dengan materi yang terdapat pada silabus K13. Pada silabus K13 sub materi organ tumbuhan termasuk ke dalam materi pokok Struktur dan Fungsi Jaringan pada Tumbuhan dan termasuk ke dalam kompetensi dasar 3.3. Namun, efektivitas dari media CD interaktif organ tumbuhan belum dapat diukur karena belum diujicobakan di sekolah. Sebelum diuji kefektifan perlu dilakukan perbaikan pada aspek isi untuk ahli materi dan aspek komunikasi visual dan audio serta rekayasa perangkat lunak untuk ahli media.

\section{SIMPULAN}

Berdasarkan hasil penelitian yang dilakukan dapat disimpulkan bahwa CD interakif organ tumbuhan dinyatakan valid dan layak digunakan dalam proses 
pembelajaran pada sub materi organ tumbuhan di kelas XI dengan rata-rata total validasi dari ahli materi sebesar 3,63 dan ahli media sebesar 3,72.

\section{UCAPAN TERIMA KASIH}

Terima kasih kepada Kepala Laboratorium Pendidikan Biologi Untan yang telah memberikan fasilitas untuk kegiatan penelitian.

\section{DAFTAR PUSTAKA}

Ambarwati, N. 2014. Pengembangan CD Interaktif IPA Terpadu Tema Kalor Berbasis Science Edutainment Untuk Siswa SMP. 3 (3): 631. (Online). (http://journal.unnes.ac.id, diakses Mei 2016).

Arkun \& Akkoyunia. 2008. Study on The Development Process of A Multimedia Learning Environment According to The Addie Model and Students' Opinions of The Multimedia Learning Environment. Interactive Educational Multimedia, 10(17): Hal. 1.

Darmawan. 2014. Inovasi Pendidikan (Pendekatan Praktik Teknologi Multimedia dan Pembelajaran Online). Bandung: Remaja Rosdakarya.

Diartono, D. A. 2008. Media Pembelajaran Desain Grafis Menggunakan Photoshop Berbasis Multimedia. Jurnal Teknologi Informasi Dinamik. 13 (2). Hal: 161. (Online). (http://www.unisbank.ac.id. Agustus 2017).

Krisnawati, T. 2014. Pengembangan Multimedia Pembelajaran Untuk Mata Pelajaran Biologi di SMA. Jurnal Ilmiah Guru "Cope". (02). Hal: 1. (Online). (http://journal.uny.ac.id, diakses April 2016).

Maya, S. D. 2013. Pengembangan Media Video Pembelajaran Pangkas Rambut Lanjutan Berbasis Komputer Program Studi Tata Rias Rambut. Jurnal Teknologi Pendidikan, 06 (01). Hal: 1. (Online) (http:// digilib. unimed. ac.id /776/. Diakses Tanggal 30 Juli 2017).

Munir. 2013. Multimedia (Konsep dan Aplikasi dalam Pendidikan). Bandung: Alfabeta.

Nurmuji, N. 2015. Model Pembelajaran Quantum Teaching Disertai CD Interaktif dalam Pembelajaran Fisika di SMA (Quantum Teaching Learning Model with Interaktive CD in Learning Physics in High School). Artikel Ilmiah Mahasiswa. I (1): 1-4. (Online). (http://repository.unej.ac.id, diakses maret 2016). 
Putra I. E. 2013. Teknologi Media Pembelajaran Sejarah Melalui Pemanfaatan Multimedia Animasi Interaktif. Jurnal Teknoif. 1(2). Hal: 1. (Online). (https://ejournal.itp.ac.id)

Ramendra, D. P. \& Ratminingsih N. M. 2007. Pemanfaatan Audio Visual Aids (Ava) dalam Proses Belajar Mengajar Mata Pelajaran Bahasa Inggris di Sekolah Dasar. Jurnal Penelitian dan Pengembangan Pendidikan. 1 (2). Hal: 78. (Online).(http://e-journal.ikippgrimadiun.ac.id,diakses Maret 2016).

Sadiman, A.. 2010. Media Pendidikan (Pengertian, Pengembangan, dan Pemanfaatannya). Jakarta: Pustekkom Dikbud dan PT Raja Grafindo Persada.

Wardani, F. T. 2013. Penggunaan Media Gambar untuk Meningkatkan Pemahaman Siswa pada Mata Pelajaran Sosiologi. (Online). (http://download.portalgaruda.org, diakses 20 Maret 2016).

Yuli, A. M. 2011. Pengembangan Media Audio Interaktif Untuk Meningkatkan Keterampilan Berkomunikasi Pada Mata Pelajaran Sains Bagi Siswa Tunanetra Kelas II di SDLB YPAB Surabaya. Jurnal Mahasiswa Teknologi Pendidikan. 1 (2) Hal: 1. (Online). (http://journal.uny.ac.id, diakses Agustus 2017). 